\title{
Introduction to Laveleye
}

\section{John Armitage and Joanne Roberts}

Émile Louis Victor de Laveleye (1822-1892) was a Belgian political economist. Laveleye was born in Bruges and educated at the Collège Stanislas in Paris, even today one of the largest and most prestigious private Catholic schools in France. Laveleye studied at the Catholic University of Louvain and later at the University of Ghent, where he was influenced by the work of François Huet (1814-1869), Professor of Philosophy at Ghent, and who is known for his attempt to reconcile Christianity with socialism in his Le Règne Social du Christianisme (1853). Schooled in the language, literature, and history of France, Laveleye's fascination with these subjects never wavered but his principal writings were in the area of political economy.

It is perhaps unusual to include a nineteenth century Belgian political economist in a twenty-first century special issue of a journal devoted to the global cultural politics of luxury. However, rare among political economists, Laveleye always displayed a keen interest in the relations between culture, understood in the philosophical sense of morality, and political economy. Indeed, in 1864, he was elected to the Chair of Political Economy at The University of Liège in 
Belgium. In this respect, Laveleye may be seen in the line of succession from John Stuart Mill (1806-1873) (Laveleye dedicated his Primitive Property of 1878 to Mill). Mill is of course one of the most frequently cited founders of modern British political economy. Mill was also a civil servant and an influential contributor to social and political theory in the nineteenth century. Although now seen as a prophet of liberty, Mill himself was actually concerned with the freedom of the individual in opposition to unrestricted state control as well as with political economy, as was Laveleye. Other influences on Laveleye include Mill's theory of "selfimprovement" in which individual development that did not impede others doing likewise led to true freedom (Mill 2008). Moreover, it was within British political economy where Laveleye thought that he saw many of his own ideals of social, political, and religious improvement fulfilled (Laveleye was a regular contributor to British newspapers and prominent political and economic periodicals). Some of the most extensively circulated of Laveleye's significant works include Protestantism and Catholicism in their Bearing upon the Liberty and Prosperity of Nations (1876), The New Tendencies of Political Economy (1879), Regulated Vice in Relation to Morality (1884), and The Socialism of Today (1886).

Yet one of Laveleye's most important and unjustly neglected books is his Luxury (1912), published during the 
build-up to World War I (1914-1918). Laveleye's Luxury raises significant questions about the political and economic costs of luxury. The book points especially toward the emotions that generate the desire for luxury. Luxury also considers the link between luxury and ethical progress. Luxury, proposes Laveleye, is not essential simply for the sake of keeping machinery working. In fact, for him, the crucial features of the issue of luxury have nothing to do with notions of the perfect life and everything to do with luxury concerning the wealth of nations, questions of justice, the state, and various types of government.

In the initial chapters of Luxury, Laveleye examines luxury as excess but also draws attention to how luxury is of growing import to the modern state and economy. This last is related in Laveleye's analysis to the rise of lavish pastimes, which he viewed harshly in 1912, as a much-expanded and thoughtless acceptance of luxury that should be censured; and whose influence on the individual's self-improvement was destructive and on society was deadly. Nevertheless, there remain pockets of confidence, kindness, and self-effacement, even in the most wasteful and unequal of societies, the latter of which, in Laveleye's opinion, Christianity and modern political economy should challenge. This was an assessment he (1912: 3-4) held both regarding luxury as "that which destroys the product of many days labour without bringing any rational 
satisfaction to the owner" and those emotions in people which generate luxury: "vanity, sensuality, and the instinct of adornment" (Laveleye 1912: 7).

In Chapter 4, "Luxury is Unjustifiable," which we publish below, Laveleye considers the theme of luxury and political philosophy in the early twentieth century, most notably, in relation to how we should interpret luxury. According to Laveleye (1912: 26), the "austere" school of political economy of the nineteenth century "preached the retrenchment of needs." It is a view that he identified as his own. But a fully-fledged "laxer" school had also been created (Laveleye gives no names), which was composed of those who considered luxury "as a thing agreeable to the individual and necessary for the state" (Laveleye 1912: 25). For Laveleye (1912: 25), the laxer school suffered from the delusion that a distinction could be made "between luxury which is honest, permissible, praiseworthy even, and luxury which is improper and immoral." Consequently, he (1912: 26) argues that the laxer school is entirely wrong because the austere school's disapproval of luxury, supported by "the philosophers and sages of antiquity," the "fathers of the Church, and the orators of the Christian pulpit," is "completely justified by the researches of modern science." Furthermore, the laxer school was remarkably ignorant of political economy. It had revolted against "the instinct of justice and of right," imagining it 
could oust Christianity and, with it, any thoughts of compassion or goodwill. European society was thus sharply divided over luxury, not only culturally but also politically. In these circumstances, the austere school and the laxer school perceived one another with reciprocal perplexity and antagonism. Essentially, Laveleye studied the circumstances that contributed to, for instance, the spirit of luxury as a depraved, unfair, and unfeeling spirit. His argument is that luxury is not only produced by people with immense natural gifts or those who possess enormous wealth and power and who endeavour to disseminate the taste for luxury but also by people who, innocently or not, at least from the perspective of modern political economy, plot against the happiness of their country. Thus, Laveleye, the political economist of the austere school, still made arguments about the cultural and political dimensions of luxury when other political economists of the laxer school had turned their attention to the stimulation of luxury production and consumption.

\section{References}

De Laveleye, Émile Louis Victor. 1876. Protestantism and Catholicism in their Bearing upon the Liberty and Prosperity of Nations. Toronto: Belford Bros. 
De Laveleye, Émile Louis Victor. Primitive Property. 1878. London: Macmillan and Co.

De Laveleye, Émile Louis Victor. 1879. The New Tendencies of Political Economy. New York: The Banker's Magazine and Statistical Register.

De Laveleye, Émile Louis Victor. 1884. Regulated Vice in Relation to Morality. London: K. Paul, Trench.

De Laveleye, Émile Louis Victor. 1886. The Socialism of Today. London: Field and Tuer.

De Laveleye, Émile Louis Victor. 1912. Luxury. London: George Allen \& Company. Available

at: https://archive.org/details/luxurylaveleyeoolaveiala (acce ssed on $7^{\text {th }}$ September 2015).

Huet, François. 2010. Le Règne Social du Christianisme. Whitefish: Kessinger Publishing.

Mill, John Stuart. 2008. On Liberty and Other Essays. Oxford: Oxford University Press.

\section{Biographies}

John Armitage is Professor of Media Arts and Co-Director of the Winchester Luxury Research Group at Winchester School of Art, University of Southampton, United Kingdom. John's 
research interests include luxury and visual culture. He is the co-editor, with Joanne Roberts, of Critical Luxury Studies: Art, Design, Media (Edinburgh University Press 2016) and the co-editor, with Jonathan Faiers and Joanne Roberts, of The Luxury Reader (Bloomsbury, forthcoming).

Joanne Roberts is Professor in Arts and Cultural Management and Director of the Winchester Luxury Research Group at Winchester School of Art, University of Southampton, United Kingdom. Her research interests include knowledge, innovation, creativity, and luxury. Joanne has published articles in a wide range of international journals, including Journal of Management Studies, Journal of Business Ethics, and Research Policy. Additionally, she has authored and edited a number of books. Her latest sole-authored book is A very Short, Fairly Interesting and Reasonably Cheap Book about Knowledge Management (Sage Publications, 2015). 


\title{
LUXURY IS UNJUSTIFIABLE
}

\author{
Emile Louis Victor de Laveleye
}

HAVING analysed the various sentiments of the human heart which give rise to luxury, we pass on to consider in what light we ought to regard it. Many authors, and among them M. Baudrillart, take up an intermediate position between the austere school, which preaches the retrenchment of needs, end the laxer school, which considers luxury as a thing agreeable to the individual and necessary for the State, making a distinction between luxury which is honest, permissible, praiseworthy even, and luxury which is improper and immoral. I, for my part, do not admit this distinction, and I believe that the austere school were altogether right. Those condemnations of luxury which, with so much unanimity and so much eloquence, have been pronounced alike by the philosophers and sages of antiquity, and by the fathers of the Church, and the orators of the Christian pulpit, are completely justified by the researches of modern science. They were ignorant of political economy, but they were inspired by the instinct of justice and of right, and, after the Christian era, by the idea of charity and of human brotherhood.

All that is really luxury cannot be other than immoral, unjust, and inhuman. Let us hear what one of the fathers of political economy has to say on this: "Those persons," said J. B. Say, "who by means of great talents or the possession of great power seek to spread the taste for luxury are guilty of conspiring against the well-being of nations."

Luxury consists, as we have seen, in the consumption of what has cost great labour to produce, for the satisfaction of spurious needs. When labour is so necessary to procure for mankind the satisfaction of legitimate needs, when so many human beings still live in almost entire destitution, can it be good or even legitimate to use a large proportion of the forces placed at our disposal by capital and labour for the production of superfluities which, indeed, in many cases, we had better be without?

In order to emphasise clearly the point wherein I venture to differ from M. Baudrillart, I will take one of his own examples, that of diamonds. M. Blanqui, writing of the Kohinoor or "Mountain of Light," had said: "Diamonds have always seemed to me very foolish and useless things, although women always covet them as the chiefest of ornaments." M. Baudrillart replies that for the year 1878 , to say nothing of the ten preceding years, diamonds found represented a value of 350 millions, that more than 20,000 workmen are employed in getting them out of mines, and more than 3000 lapidaries of Holland, Belgium, and France in 
cutting them, and that these earn good salaries, half-a-crown for the apprentices, and the master lapidaries from 12s. to 16s. "Is all this," he asks, finally, "of no use at all ?"

It is my opinion that a thing may be valued at enormous sums, and be, not only quite useless, but very harmful. The Chinese buy from the English $£ 16,000,000$ worth of opium; this is worse than useless. It is a poison, and the Emperor of China would do well to fling into the sea all the cases of this abominable narcotic which England palms off upon him. These are what I call false riches. To maintain that wealth consists of labour is, as Bastiat says, nothing but a sisyphism, or making work for work's sake. I see thousands of workers, it is true, at work in the mines or in the shops, and receiving good salaries. But if the diamonds which they are finding, or cutting, have no other effect than to excite bad feeling, to arouse vanity in those that possess them, and envy in those who cannot, would it not be better to seek the ocean-bed for these precious stones, in company with the opium? If these same workers were employed in making shirts, and shoes, and stockings for those who have none, would there not be better cause for congratulation? For my own part, I would rather see fifty women each wearing a dress that cost a pound then one wearing a ball-dress which cost $£ 400$.

I am not calling for sumptuary laws, but I rejoice when I see a country like Norway, and the mountain Cantons of Switzerland, where no one buys diamonds, but everyone has sufficient means to procure the necessaries of life.

The main point, and the one which is most often forgotten, is this: every article of luxury costs much labour - could not this labour be utilized in a more rational fashion? If we take the case of an isolated individual, we shall see more clearly the point of this.

Would any man be insane enough to devote three years of his existence to making himself a piece of jewelry which in point of fact will be of no real use to him? It is the phenomena of exchange which hide from us the absurdity of it, the fact that he who wears it has ordered it from some one else. But when we consider the whole of humanity as one being, obliged to satisfy his wants by his labour, we can see clearly that it is folly for him to waste precious time in cutting diamonds, if he still has often to walk with bare feet. The inhabitants of any country have but a certain limited number of hours in the day to dispose of; if they devote half this time to making useless trifles, it is inevitable that half the population should go without the necessaries of life. An Emperor of China once said: "If one of my subjects is idle and does not work then there is somewhere in my State another who suffers from hunger and cold." To dig a hole and fill it up again, to embroider shirt-fronts, or set precious stones, is not really to work, for it is not productive of the least utility. 
My quarrel with M. Baudrillart is not for being too indulgent towards what he calls "mischievous luxury"; it is for admitting that there can be luxury which is not mischievous. Luxury, to my thinking, cannot be other than mischievous. The very word, it seems to me, implies an idea of blame. When he deals with "mischievous luxury," M. Baudrillart attacks it eloquently and with energy. Let us hear him: "Men were right in regarding as an axiom the proposition: luxury is enervating. They were not less right in adding: and it corrupts. It destroys the manly energy of the mind by cultivating a taste for mere enjoyment, and a pride in mere frivolity. It kills the spirit of self-sacrifice, without which no society can continue to exist; it undermines at once the power of any lively impulse towards good, and of any determined resistance of evil. Men live for the sake of pleasure; public spirit ceases to have any motive power. Historians and moralists are unanimous in pointing out the inevitable decay which follows on the worship of ease and refinement, and the debasement of character which this produces. More than ever, in our days, the mere owner of wealth, idle and dissipated, seems a shocking anomaly. We are finding it hard to accept the idea of rights without duties. Luxury then brings moral discredit on ownership, dissipating in frivolity and wrongdoing."

In another fine passage, M. Baudrillart sums up Rousseau's diatribe against towns, though, he adds, that in this matter we must not forget what statistics show as to the advantages they procure and the virtues they develop. "Towns are hot-beds of luxury and corruption! It is there that men's wants are overexcited by a thousand stimulants, it is there that are crowded together all those species of delights which do not wait upon desire but call it forth. There all the vanities and all the vices spread in contagious competition. The art of frivolity settles on the ruins of the useful arts, nay, the very necessary arts which serve the needs of all are choked out of existence by this flux of superfluities which are serviceable only to the few. Every moment the revolting contrast strikes one between excessive opulence and extreme misery - rags, tatters, and even nakedness, on the one hand, and on the other the flaunting array of all the trappings of opulence. Here, splendid dwellings; there, a hearth without a fire; here, vice, elegant and gay; there, vice in its most brutal form, the crime of those who seek both vengeance on, and a participation in this wealth which crushes them down. For them there is temptation everywhere; shops by thousands, filled with all that the poor lack, displaying stores of gold, jewels, and fine costumes. Out of this state of things spring hatred and envy in the hearts of the poor, raging there in secret, only to break out from time to time in those tumults in which he who has nothing seeks to enforce a claim to his share of enjoyment." What more could be said even by the most fervent disciple of the austere school, whom, nevertheless, M. Baudrillart taxes with extravagance? But the point of difference is that he regards a certain degree of luxury - a moderate, and not 
immoral degree, of course - as an indispensable stimulus to work which would not be found in the supply of necessary wants alone. In this I cannot agree with him, and I will proceed to give my reasons.

I admit with Stuart Mill that, in order to arouse those races which are still in the savage state from the sort of animal inertia and dull stagnation in which they live, it may be good to excite in them new wants which will make them work and contrive in order to satisfy them. But among the nations of Europe it is not the desire for consumption which needs stimulating. "Nay, but see," says M. Baudrillart, "the wretched creatures crowded into the cellars of Lille, the dosshouses of London. They are happy in their dirt and darkness, and have no desire to come out of it." I ask, Is this reproach well-founded? These unfortunate creatures work, nevertheless; they toil and suffer to earn subsistence. Can we reproach them with the fact that what they can earn is so insufficient that it drives them into holes and corners where a farmer would not house his dogs or even his pigs? The very large majority of even a rich nation like the French has not the lodging, furniture, raiment, or food, which hygiene prescribes, and they all most certainly wish for it. Is it possible that this desire for the necessaries of life would not be strong enough to stimulate men to work? It is the only stimulus of those who perform manual labour, and it is precisely the idle who seek for superfluities.

"But what will you do, wiseacres," cries M. Baudrillart, "with the thousands of artists and hundreds of thousands of workmen who work in metals, stuffs, ivory, wood, or gems, executing products of infinite taste?" Yet, some pages further on, the eminent economist himself answers this question, in refuting the argument of those who maintain that "France produces too much." "In what respect does she produce too much, this happy country of ours? It is not in respect of the whole sum of useful and pleasant things in life - for there are too many poor! Show me, if you can, the article which is produced in superabundance. Is it flannel, when so many are cold? Is it corn, when so many lack bread?"

Here lies the solution of the problem: those workmen who work in ivory and in gems should produce the flannel and the corn which you say are so much wanted now, and the problem would be solved. The same amount of work, but of a more useful kind.

"But you cannot distinguish," our author goes on to urge, "between the superfluous which you mean to proscribe and the necessary you wish to multiply." It is true the idea of luxury is relative and depends on the means of production: what is superfluous to-day will be no longer so to-morrow, if the progress of the mechanical arts have placed it within reach of all. Yet, for all that, I hold that the distinction is always easy to make: is an object worth the pain it would require and the time it would take for me to make it myself? If so, it is not a luxury, 
and I am right in securing it; but if, in obtaining it, I divert human effort from a channel in which it would be more useful, I am wrong. I sacrifice things necessary to things superfluous. I am making a bad use of my own or my fellow-creatures' powers. 